Leonard G. Sbrocchi. I verbi italiani (et leurs équivalents français, and their English equivalents). Ottawa, Toronto, New York: LEGAS, 1989. Pp. 198.

This book represents a first attempt at cataloguing the conjugations of the Italian verbs side by side with their French and English equivalents. A brief introductory note supplies the reader with an explanation of the rationale behind such an endeavour. The author states that his purpose is to point out difficulties in the use of certain forms which do not have a counterpart in all three languages, as for example in the case of the Imperfetto Indicativo or the Gerundio / Participio.

The material is divided into the following sections: 1. auxiliary verbs: this section includes all simple and compound tenses for both essere and avere; 2. regular verbs: besides those of the three conjugations, including regular verbs ending in -care, -gare, -giare, -ciare which undergo orthographic changes, this section includes the prototypes of the conjugations of the Reflexive forms and of the Passive transformation; 3. irregular verbs of the first conjugation; 4. irregular verbs of the second conjugation; 5. irregular verbs of the third conjugation; 6. modal (referred to in the text as "servile") impersonal, defective, superabundant verbs (literal translation of "sovrabbondanti," that is, with more that one form): this section includes their definition and some contextualized examples of their use; 7. a Verb Index.

The help that such a reference tool can provide to $L_{2}$ learners and teachers alike is unquestionable. Of special interest, for example, is the Verb Index at the end of the volume, in which verbs are listed with their transitive / intransitive function, the type of auxiliary forms they take, (essere / avere), and their preposition(s), when applicable: i.e. Arrossire (intr. ess.), Cercare (tr. av., di), Consigliare (tr. av., a, di). Not only can this Verb Index make studying and reviewing easier for the student, but it can also be of great use to the teacher in the preparation of exercises and test items.

In this book, however, there are some shortcomings which involve the very essence of the points which the author intends to clarify. As we know, Italian and French have five different forms in the indicative to express the past tense (Passé Composé / Passato Prossimo, Imparfait / Imperfetto, Plus-Que-Parfait / Trapassato Prossimo, Passé Simple / Passato Remoto, Passé Anterieur / Trapassato Prossimo). English, instead, lacks specific forms of the Imparfait / Imperfetto and the Passé Anterieur / Trapassato Prossimo. The presentation of the forms of the Past Descriptive, given in the book as equivalent to the Imparfait / Imperfetto Indicative, constitutes the first problem. We see inexplicable shifts from I had (19) to I was (22) for the auxiliary verbs, and from I talked (27), I yielded (30), I left (33), for most of the regular verbs, to I used to finish (36), I used to fish (39), I used to tie (41) etc. for all the remaining verbs. Not only is such an inconsistency a source of confusion for the learners, but it misleads them into assuming that only one of the two forms is accurate. In actual fact, the imperfect can be translated into English with both forms depending on the context, as in the following examples: "Da bambino andavo a scuola in bicicletta" / "As a child I used to ride my bike to school;" "Ho preso due aspirine perché avevo un forte mal di testa" / "I took two aspirines because I had a terrible migraine." As for the Passé Anterieur / Trapassato Prossimo, the book manufactures an English equivalent, the 2nd Past Perfect (with the same form as the Past Perfect) in order to establish "a precise correspondence between the verbs of the language to be learned and those of the mother tongue" (13). It seems that the students, to whom this book is addressed, would benefit a great deal from a more detailed account of the rationale behind such 


\section{alleged "correspondences."}

One last comment seems to be in order. As the author has correctly pointed out, students have a great deal of difficulty with the forms of the Gerund and the Participle. English-speaking students of Italian, for example, are panic-stricken whenever they have to find the equivalent of an English -ing form. The text gives the Participio Presente as the only counterpart of the Participle, thus proposing forms such as "parlante," "corrente," "inviante" as equivalent to "talking," "running," "sending." Following this type of equivalence, students will therefore diligently translate: "I saw a child running in the yard" as "Ho visto un bambino corrente nel giardino," rather than "Ho visto un bambino che correva nel giardino."

Students should also be made aware that very frequently the -ing form in English finds its Italian equivalent in the Infinito, as for example in: "Running is good for your circulation" / "Correre fa bene alla circolazione;" "I don't like going to the dentist" / "Non mi piace andare dal dentista."

In spitc of the flaws mentioned, which can be easily corrected in a second edition, this text deserves to be on the "recommended" list for learners of Italian as a Second Language (ISL) at every level of proficiency.

\section{MARINA FRESCURA}

York University 